\title{
Analysis of Marketing Margins and Efficiency of Cassava-based Product in Cross River Central Agricultural Zone, Nigeria
}

\author{
I. O. Ettah ${ }^{1}$, E. Agbachom Emmanuel ${ }^{1}$, Ajigo Ikutal $^{2}$ and Godwin Michael $\mathrm{Ubi}^{{ }^{*}}$ \\ ${ }^{1}$ Department of Agricultural Economics, Faculty of Agriculture, Forestry and Wildlife Resources \\ Management, University of Calabar, P.M.B. 1115, Calabar, Nigeria. \\ ${ }^{2}$ Department of Vocational and Special Education, Faculty of Education, University of Calabar, \\ P.M.B. 1115, Calabar, Nigeria. \\ ${ }^{3}$ Department of Genetics and Biotechnology, Faculty of Biological Sciences, University of Calabar, \\ P.M.B. 1115, Calabar, Nigeria.
}

\section{Authors' contributions}

This work was carried out in collaboration among all authors. Author IOE designed the study. Authors $I O E$ and GMU performed the statistical analysis. Authors IOE, EAE and Al wrote the protocol. Authors IOE and GMU wrote the first draft of the manuscript. Authors IOE and GMU managed the analyses of

the study. Authors AI and EAE managed the literature searches. All authors read and approved the final manuscript.

\section{Article Information}

DOI: $10.9734 / A R R B / 2019 / v 34 i 530165$ Editor(s):

(1) Dr. Lucas Petigrosso, Ecology in Faculty of Agrarian Science of the National University (FCA-UNMdP), Argentina. Reviewers:

(1) Emmanuel Dodzi. Kutor Havi, Methodist University College Ghana, Ghana. (2) M. V. Chandramathi, India. (3) Hussin Jose Hejase, Al Maaref University, Lebanon Complete Peer review History: http://www.sdiarticle4.com/review-history/54505

Original Research Article

Received 10 December 2019

Accepted 13 February 2020

Published 03 March 2020

\section{ABSTRACT}

The study was carried out to determine marketing margins in the marketing of garri in Cross River Central Agricultural Zone, Nigeria. The study employed primary data which were obtained directly from garri marketers and analyzed with the use of descriptive statistics and marketing efficiency model. A three-stage (multi-stage) sampling technique was used in the selection of respondents and using $10 \%$ proportionality a sample size of 196 respondents was obtained from the sample frame of 1960. Analysis of the result showed that garri marketing in the area is greatly influenced by the socio-economic characteristics of garri marketers. Furthermore, the result indicated that 
marketers in Ofodua and Ochon markets recorded the lowest margin of 200 per bag of garri. This is against the 300 margin recorded by marketers in Apiapum, Okuni, Nko and Akparabong markets, 400 for markets in Ugep and Ikom Urban and $\$ 600$ for the market in Agoi, respectively. The average marketing margin for garri in the markets was $\$ 378$. Producers of garri sell it to the wholesalers in bulk sometimes through intermediaries like the village agents or directly to them. Retailers obtain the product from wholesalers and retail directly to final consumers also sometimes passing through movement agents and cooperative consumer outlets before reaching the final consumer. The mean marketing efficiency for garri across the study area is 0.78 . This is slightly lower than the average efficiency level for Ugep, Apiapum and Ikom urban markets $(0.90,0.8$. and 0.90 , respectively). The following were recommended: trading activities and attributes of garri traders should be regulated by governments to ensure efficiency in the business, government, corporate bodies and NGO's should assist in the rehabilitation of feeder roads to guarantee easy movement of garri from the producers to the consumers and traders in garri should be provided with training by government to increase their efficiency in the distribution of garri.

Keywords: Garri; profit margin; market; distribution channel; farm gate prices.

\section{INTRODUCTION}

According to Hejase and Hejase [1], marketing is the process by which agricultural products flow from the producers to the consumers to effect the exchange of goods and services that satisfy the needs of individuals, groups or the entire society. $\mathrm{He}$ further posited that in the process of marketing, buyers and sellers are linked together and can react to current situations especially price in reaction to the forces of supply and demand. Participants thereby generate incomes which enhance their production and welfare. An effective and efficient marketing system enhances consumption, output and economic development.

Marketing margin is an equilibrium entity that is a function of the difference between the equilibrium of retail and farm prices [2]. The margin provides neither a measure of farmer's well-being nor of the marketing firms' performance and also indicates the market structure and efficiency. Marketing margin for a particular commodity is the difference between what the consumer pays for the final product and the amount the producer receives and at each intermediary level, it is the difference between the price received on resale and the purchase price $[3,4]$. Marketing margin reflects the costs and profit of middlemen and has remained an important tool in analyzing the performance of marketing systems.

Garri is a staple food prepared from the roots of cassava (Manihot esculenta crantz). Its importance in bridging the food gap in Nigeria cannot be overemphasized [5]. In recent times, many rural households have anchored their livelihood on garri processing and marketing.
This is because of the strategic position of garri in the food marketing systems of Nigerians and it is the most common form in which cassava is consumed and marketed [6,7]. They further held that more than half of the garri produced in rural areas of Nigeria are destined for sale; the producers usually take the garri to urban markets for sale to the final consumers. The study specifically focused on the analysis of marketing margins in the marketing of garri in the study area, with the following specific objectives:

I. Describe the socio-economic attributes of garri marketers in area

II. Determine levels of marketing margin of garri marketers in the study area

III. Identify the main channel of distribution of garri

The following hypotheses guided this study:

I. Levels of marketing margin do not significantly influence garri marketing in the study area

II. Socio-economic attributes do no significantly influence garri marketing and their marketing margins in the area

\section{MATERIALS AND METHODS}

\subsection{Methods of Data Collection and Analysis}

The study employed primary data. Primary data were obtained directly from garri marketers in the Cross River Central Senatorial zone. A threestage (multi-stage) sampling technique was used in the selection process. In the first stage, three (3) Local Government Areas (LGAs.) were purposively selected from the six (6) LGAs 
making up the zone, because of the preponderance of garri marketing activities in those LGA's. In the second stage, three (3) villages were randomly selected from each of the local government areas earlier selected giving a total of nine (9) villages. The third stage involved obtaining a list of garri marketers from registered garri marketers association in the study area. Using $10 \%$ proportionality a sample size of 196 respondents was obtained from the sample frame of 1960, as shown in Table 1. Furthermore, according to Ekubika [8], "descriptive statistics deals with describing a collection of data by condensing the amounts of data into simple representative numerical quantities or plots that can provide a better understanding of the collected data." Therefore, this study analyzed data collected with descriptive statistics such as frequency distribution tables, percentages, mean scores and graphical representations. Moreover, the marketing efficiency model is used to capture specific objectives.

\subsection{Model Specification}

\subsubsection{Marketing efficiency model (Shepherd model of marketing efficiency)}

This model is concerned with the productivity of the resources used in the production and marketing process (in quantitative terms) by computing the coefficient of marketing efficiency (CME) this is the ratio of estimated costs incurred by marketing agencies and producers combined, to the value of product sold and expressed in percentage, it is given as:

$$
\text { CME }=(T C / T R \times 100 / 1)
$$

Where

$$
\begin{aligned}
& \text { CME }=\text { Coefficient of Marketing Efficiency } \\
& \text { TC }=\text { Total Cost of marketing } \\
& T R=\text { Total Revenue from marketing }
\end{aligned}
$$

Marketing efficiency is the maximization of the ratio of the output of marketing to the input of marketing and is given as:
Marketing efficiency $=($ Value of output $/$ Value of input X 100/1)

The higher the coefficient obtained, the higher the marketing efficiency $[1,9]$.

\section{RESULTS AND DISCUSSION}

\subsection{Socio-economic Attributes of Garri Marketers}

The analyzed result of socio-economic attributes of garri marketers concerning age, sex, marital status household size, educational qualification, trading experience, business size, annual income is presented in Table 2.

Entries in Table 2 show that $40.3 \%$ of the garri marketers examined were between the ages of $31-45$ years. The mean age was 43 years, which implies that the majority of the traders were within an active age. This result is consistent with the finding of [10] who also found that the cassava farmers they studied were within the same mean age of 43 years. This age portends activeness of traders in the business and decision making. The result, however, contradicts that of [11] who found an average age of 50 years for garri marketers in their analysis of the marketing of garri in Delta State, Nigeria.

The result also shows that $75 \%$ of the garri traders were females, while $25 \%$ were males which mean that more females than males were involved in trading activities in the study area. This result is variance to the findings by $[8,11]$ that garri trading activities are dominated by males and production by females. The marital status of respondents show that $60.7 \%$ were married, $20.1 \%$ not married and $10.2 \%$ widowed respectively. This result is an indication that garri traders use this business to cater for their families. This result also agrees with that of $[11,12]$ that most of the garri traders are married with high household size.

Table 1. Selection of respondents in the study area

\begin{tabular}{lllll}
\hline S/N & LGA & Villages & $\begin{array}{l}\text { Sample } \\
\text { frame }\end{array}$ & $\begin{array}{l}\text { Sample size (Number } \\
\text { of respondents) }\end{array}$ \\
\hline 1 & Yakurr LGA & Ugep, Agoi, Nko & 600 & 60 \\
2 & Obubra LGA & Ofudua, Ochon, Apiapum & 800 & 80 \\
3 & Ikom LGA & Ikom Urban, Okuni and Akparabong & 560 & 56 \\
\hline Total & $\mathbf{3}$ & $\mathbf{9}$ & $\mathbf{1 9 6 0}$ & $\mathbf{1 9 6}$ \\
\hline \multicolumn{7}{r}{ Source: field survey, 2018 } \\
\end{tabular}


Table 2. Socio-economic characteristics

\begin{tabular}{|c|c|c|c|}
\hline Variable & Frequency & Percentage (\%) & Mean \\
\hline \multicolumn{4}{|l|}{ Age (years) } \\
\hline $15-30$ & 24 & 12.3 & \\
\hline $31-45$ & 79 & 40.3 & \\
\hline $46-60$ & 61 & 31.1 & \\
\hline 61 and above & 32 & 16.3 & \\
\hline Total & 196 & 100 & 43 \\
\hline \multicolumn{4}{|l|}{ Sex } \\
\hline Male & 49 & 25 & \\
\hline Female & 147 & 75 & \\
\hline Total & 196 & 100 & \\
\hline \multicolumn{4}{|l|}{ Marital Status } \\
\hline Married & 119 & 60.7 & \\
\hline Not Married & 57 & 29.1 & \\
\hline Widowed & 20 & 10.2 & \\
\hline Total & 196 & 100 & \\
\hline \multicolumn{4}{|c|}{ Household Size (number) } \\
\hline $1-5$ & 75 & 38.7 & \\
\hline $6-10$ & 82 & 41.8 & \\
\hline 11 and above & 39 & 19.9 & \\
\hline Total & 196 & 100 & 9 \\
\hline \multicolumn{4}{|c|}{ Educational Qualification (years) } \\
\hline $1-6$ & 71 & 36.2 & \\
\hline $7-12$ & 92 & 46.9 & \\
\hline $13-18$ & 24 & 12.3 & \\
\hline 18 and above & 9 & 4.6 & \\
\hline Total & 196 & 100 & 10 \\
\hline \multicolumn{4}{|c|}{ Trading Experience (years) } \\
\hline $1-10$ & 64 & 32.7 & \\
\hline $11-20$ & 73 & 37.2 & \\
\hline $21-30$ & 34 & 17.3 & \\
\hline 31 and above & 25 & 12.8 & \\
\hline Total & 196 & 100 & 9 \\
\hline \multicolumn{4}{|c|}{ Number of bags of garri $(50 \mathrm{~kg})$} \\
\hline $40-60$ & 43 & 21.9 & \\
\hline $61-80$ & 76 & 38.8 & \\
\hline $81-100$ & 57 & 29.1 & \\
\hline 101 and above & 20 & 10.2 & \\
\hline Total & 196 & 100 & \\
\hline \multicolumn{4}{|l|}{ Annual Income ( } \\
\hline $100000-200000$ & 85 & 43.4 & \\
\hline $201000-300000$ & 68 & 34.7 & \\
\hline $301000-400000$ & 28 & 14.3 & \\
\hline 401000 and above & 15 & 7.7 & \\
\hline Total & 196 & 100 & 196000 \\
\hline
\end{tabular}

The result further shows that $41.8 \%$ had the household size of $6-10$ members, while $19.9 \%$ have a household size of 11 members and above. This result is an indication that most of the traders have a sizeable household size. This could be because of the high percentage of respondents who are married and also shows a high dependency on the income of the business.
This result was in line with the findings of Olukosi and Isitor [13] who found out that a higher proportion of the respondents had household size of 6-10 members, findings further contradicts that of [12], who found an average household size of 5 persons in a study of the structure of Ofatura goat market Obubra Local Government Area of Cross River State. 
Educational qualification of the respondents shows that $46.9 \%$ had between 7 to 12 years of formal education. This means that garri traders had a good level of education (secondary school education) that will enhance the marketing of the product. This result contradicts [14] who found out that majority of the garri traders studied had either no formal education or had primary education (1-6 years) only.

The result of the trading experience further shows that $37.2 \%$ which formed the majority had the trading experience of 11 to 20 years. The long years of trading experience are because this business is predominant in the area as a result of the large scale production and consumption of the product (garri). On the number of bags of garri $(50 \mathrm{~kg}$ bag), the majority $(38.8 \%)$ had the business size of $81-100$ bags, per month. This result means that the majority of the traders are small scale garri traders. This finding agrees with the findings of Okoh and Egbon [14] whose study showed that majority of the garri traders examined were small scale traders, with no large warehouses.

As many as $43.4 \%$ of the garri traders representing the majority made an income of N100,000- N 200,000, with a mean income of N196,000. This result shows that the income received from garri trading in the study area is poor. This result disagrees with that of [13] who found out that small scale entrepreneurs should have an income of between N150, 000 and N200, 000 per month to be able to break- even and make a reasonable profit.

\subsection{Marketing Margin Analysis}

Marketing margin measures the share of the final selling price that is obtained by a particular agent in the marketing chain. It is the difference between the price paid by the consumer and that received by the producer. Table 3 shows the marketing margin for garri across the selected markets studied. Marketers in Ofodua and Ochon markets recorded the lowest margin of $\$ 200$ per bag of garri.

This is against the $\$ 300$ margin recorded by marketers in Apiapum, Okuni, Nko and Akparabong markets, 400 for markets in Ugep and Ikom Urban and $\$ 600$ for the market in Agoi, respectively. The average marketing margin for garri in the markets is 378 which is slightly lower than the marginal values in Ugep, Ikom Urban and Agoi markets, respectively and greater values in Ofodua, Ochon, Apiapum,
Okuni, Nko and Akparabong markets, respectively. This implies that a fairly moderate margin recorded in Apipum, Okuni, Nko and Akparabong markets may have been caused by the series of marketing activities involved in garri and some other food items and the poor marketing system. This result is in agreement to that of $[9,13]$ marketing activities involved in garri and poor marketing system caused low marketing margin in the study: determinants of the technical efficiency in garri processing in Delta State, Nigeria. The result contradicts that of [15] in their study of sustaining garri enterprise for rural livelihood they found out a high a marketing margin of an average of $\$ 500$.

The rule of thumb is that a very wide margin between the producer's price and wholesaler price is an indication of an inefficient marketing system. In an efficient marketing system, the margin should be a function of transportation and other transaction cost incurred in carrying garri from producers to the wholesalers. The marketing margins of $\$ 200, \# 400$ and $\$ 600$ respectively recorded shows that differences exist in the estimated markets based on this result, the null hypothesis that there is no significant difference in the marketing margin between the different garri markets in the study area is hereby rejected.

\subsection{Marketing Channels of Garri Distribution in the Study Area}

Marketing channel of garri in the area indicates the process of making garri available to the consumers. Fig. 1 shows the marketing channel of garri sellers in the study area. Further, Fig. 1 shows that the producers produce the garri and sell it to the wholesalers in bulk sometimes through intermediaries like the village agents or directly to them. Retailers obtain the product from wholesalers and retail directly to final consumers also sometimes passing through movement agents and cooperative consumer outlets before reaching the final consumer. Onyeabor [16] in their study sustaining garri enterprise for rural livelihood also found a similar channel of movement of garri from the producers to the consumers.

\subsection{Marketing Efficiencies in Garri Marketing in the Study Area}

Table 4 shows the marketing efficiency values across the selected markets studied. The mean marketing efficiency for garri across the study area is 0.78 . 
Table 3. Marketing margin for garri sellers in the study area

\begin{tabular}{llll}
\hline Market & Wholesale price (N) & Producers Price (N) & Market Margin (N) \\
\hline Ugep & 2700 & 2300 & 400 \\
Agoi & 2600 & 2000 & 600 \\
Nko & 2500 & 2200 & 300 \\
Ofodua & 2600 & 2400 & 200 \\
Ochon & 2600 & 2400 & 200 \\
Apiapum & 2600 & 2300 & 300 \\
Okuni & 2700 & 2400 & 300 \\
Ikom Urban & 2800 & 2400 & 400 \\
Akparabong & 2700 & 2400 & 300 \\
\hline Average & $\mathbf{2 , 3 5 6}$ & $\mathbf{2 , 0 0 0}$ & $\mathbf{3 7 8}$ \\
\hline
\end{tabular}

Source: field survey, 2018

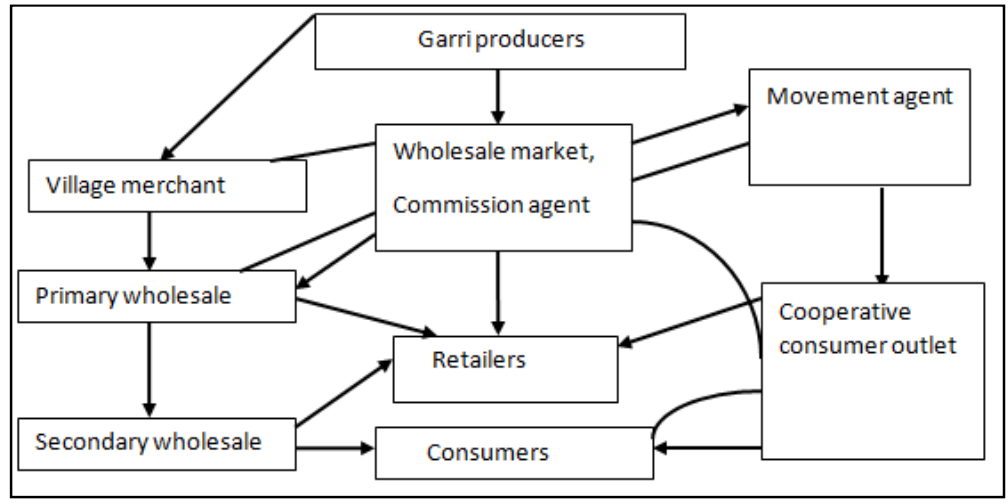

Fig. 1. Channel of distribution of garri

Table 4. Levels of efficiency in marketing of garri in the area

\begin{tabular}{ll}
\hline Market & Efficiency Level \\
\hline Ugep & 0.90 \\
Agoi & 0.50 \\
Nko & 0.60 \\
Ikom Urban & 0.90 \\
Akparabong & 0.60 \\
Okuni & 0.70 \\
Apiapum & 0.80 \\
Ochon & 0.70 \\
Ofodua & 0.60 \\
\hline Average & $\mathbf{0 . 7 8}$ \\
\hline \multicolumn{2}{c}{ Source: field survey, 2018 }
\end{tabular}

This is slightly lower than the average efficiency level for Ugep, Apiapum and Ikom urban markets $(0.90,0.8$. and 0.90 , respectively). Agoi had the least marketing efficiency value of 0.50 . This low marketing efficiency value may be attributed to the inability of garri marketers in this area to carry out effectively the various marketing functions which could have helped to strengthen their marketing efficiency. Garri is efficiently marketed in Ugep and IKom urban hence the highest marketing margin of 0.90 . The high average marketing efficiency could be attributable to the long trading experience. This result agrees with that of [17], who also found efficient garri marketing in South-Western Nigeria. Furthermore, the result is in variance to that of $[6,18]$, who found a low marketing efficiency in their study of the determinant of the technical efficiency in garri processing in Delta State.

\section{CONCLUSION AND POLICY RECOMMENDATIONS}

Analysis of the results revealed that garri marketing in the area is greatly influenced by socio-economic characteristics of garri marketer. The marketing margins of $\$ 200, \$ 400$ and $\$ 600$ respectively recorded shows that differences exist in the estimated markets and it is attributed to intermediary agents between the producers and consumers of garri. The following recommendations were proffered: trading activities and attributes of garri traders should be regulated by governments and other stakeholders to ensure efficiency and entrepreneurship in the business; government, corporate bodies and NGO's should assist in the rehabilitation of feeder roads to guarantee easy movement of garri from the producers to the 
consumers; traders in garri should be provided with training by government to increase their efficiency in the distribution of garri to the consumers and appropriate policies should be made by government to reduce intermediaries such as commission agent, primary and secondary wholesalers, village merchant, etc. to ensure reasonable pricing to consumers.

\section{COMPETING INTERESTS}

Authors have declared that no competing interests exist.

\section{REFERENCES}

1. Hejase AJ, Hejase HJ. Research methods: A Practical Approach for Business Students (2nd edition). Philadelphia, PA, USA: Masadir Inc; 2013.

2. Jayara D. Spatial pricing efficiency in garri markets: Tamic Nadu: Indian Journal of Agricultural Economics. 1992;47(1):79-89.

3. Ali E, Gaya H, Jampada N. Economic analysis of marketing margins in Maiduguri Gamburu Market Kachallari Alau Dam Landing Site of North Eastern. Journal of Agricultural and Social Sciences. 2007; 4(2):3-6.

4. Ngoddy PO. Determinants of the development of technology for processing roots and Tuber in Nigeria, National Root Crops Research Institute Umudike; 1997.

5. Arene CJ. Agricultural economics. A functional approach. University of Nigeria Press, Enugu, Nigeria; 2008.

6. Chukwuji CO, Inoni O, Ike N. Determinant of the technical efficiency in Garri Processing in Delta State, Nigeria. Journal of Central European Agriculture. 2007; 8(3):329-330.

7. Ebewore S, Eldoge OD. Analysis of Marketing of Garri in Delta State, Nigeria. Journal of Northeast Agricultural University. 2015;2(12).

8. Ekubika E. Economic analysis of cassava production farming in Akwa Ibom State, Nigeria. Agric. Biol. Am. 2010;4(2):24-31.

9. Adinya IB, Enya VE, Kuye OO. Structure of Of atura Goat Market Obubra Local
Government Area of Cross River State. Global Journal of Agricultural Sciences. 2007;6(1):55-59.

10. Kuye OO, Ettah OI. Analysis of socioeconomic factors affecting cassava production and value chain in lkot Ekpene Local Government Area of Akwa Ibom State, Nigeria. Proceedings of farm management association of Nigeria (FAMAN) Abuja, $28^{\text {th }}-2^{\text {nd }}$ December; 2016.

11. Funke O, Raphael B, Kabir S. Market Structure, Conduct and Performance of Garri Processing Industry in South Western Nigeria. European Journal of Business and Management. 2012;2(3).

12. Lemchi J, Ifeanyi-Obi CC, Olatunji SO. Socio-Economic Factors Affecting the Marketingof Garri in Port Harcourt City of Rivers State. Journal of Agriculture and Social Research (JASR). 2011;4(6).

13. Olukosi JO, Isitor S. Introduction to agricultural marketing and prices, principles and applications. Living books series. G. U. publications, Abuja Nigeria; 1990.

14. Okoh R, Egbon P. A Test of markets integration: The case of Nigerian staple food stuffs. African Economic Research Consortium Report. 2002;9(2).

15. Ekwe C, Ike N. Sustaining Garri enterprise for rural livelihood: Farmers indigenous Innovation in Southern Nigeria, MPRA Paper. 2010;3-6.

16. Onyeabor EN. Agricultural marketing for developing countries: John Jacob classic publishers, Enugu Nigeria; 2009.

17. Agboachom EE, Amalu M, Uzoikwe A, Ettah I, Ubi GM. Strategic policies in expanding frontiers of food security among cassava -based farmers in Cross River State, Nigeria. Annual Research \& Review in Biology. 2019;33(5):1-12.

18. Ubi GM, Kinglsey EN, Onabe MB, Jemide JO, Egu CJ. Organoleptic and horticultural characterization of Elite Cultivars of Plantain (Musa paradisiaca L.) for value addition and food security in Nigeria. Journal of Advances in Biology and Biotechnology. 2016;9(1)1-21.

(c) 2019 Ettah et al.; This is an Open Access article distributed under the terms of the Creative Commons Attribution License (http://creativecommons.org/licenses/by/4.0), which permits unrestricted use, distribution, and reproduction in any medium, provided the original work is properly cited.

Peer-review history:

The peer review history for this paper can be accessed here: http://www.sdiarticle4.com/review-history/54505 